\title{
Critical analysis of the Fall of Fiqa - Yi Democrat Azerbaijan, (Iran, 1946)
}

\author{
Najleh Khandagh \\ Tarbiat Modarees University,Tehran
}

\begin{abstract}
This article examines the Firqa - Yi Democrat Azerbaijan an autonomous movement, supported popularly and caused by the historical circumstances of Reza Shah's dictatorship (1921-1941) and subsequence central government pressure which culminated in the rejection by the Majlis of Pishavari's credentials. Despite increasing governmental pressure the movement became self - governing and was supported by the Soviet Union though opposed by America and Britain, which opposition ultimately aided its downfall, though not before a considerable number of beneficial reforms had been carried out in the province. This field has been hitherto unexplored due to the need to know Azari Turkish. Persian and English, and because in the Pahlavi period investigation was difficult, materials scarce and interviews very dangerous. Only after the fall of the Shah has there been the chance to undertake original work and publish conclusions. with the international reaction, the role of the United Nations, and that of the Prime Minister, Qavam, who concluded agreements with the Firqa - Yi Democrat leader and the USSR. The successful pressure from the West and the U.S. on the central government to crush the movement and the international agreement between America and the USSR, are analyzed. Finally, the causes of failures of the movement and the subsequent ban on all political parties .
\end{abstract}

Key words : Azerbaijan - Firqa Yi Democrat - pishavari - Qavam - foreign intervention central government - Soviet Union - united State of America - Britain

\section{INTRODUCTION}

Azerbaijan has always been a revolutionary province. She has always suffered from neglect and discrimination and remained sadly under - developed despite enjoying rich natural resources. As not only an Azari, but an Azeri with a strong interest in politics. I have been intrigued by the cases of such a state.

However my efforts to study this feeled more deeply were made more difficult by the paucity of materials, utterly out of proportion to the complexity and importance of the subject. What little was consisted of charges against Pishavari, alleging treachery, adventurism and crude separatism .

I was naturally puzzled by the contradiction between my childhood understanding of the Firqa - Yi Democrat as a worthwhile, reforming movement, and the official, written claim condemning the episode. I wanted to establish the truth. What frightens so many people about this movement? Was it a good or bed thing for Azerbaijan? What was the reason for the central government's sensitivity? What factors contributed to the course of events that we understand took place? why it achieved such a degree of popularity and success in its year of existence, and exactly why it suffered opposition from the government, conservative force and influential Western powers. 
The establishment of the Democrat party of Azerbaijan has been traditionally interpreted by both Western and Persian scholars as nothing but a soviet creation. It is an approach characterized by the importance given to the role of the Soviet Union within the province of Azerbaijan: the presence of this Communist regime has been assumed to have been such a powerful factor that the establishment of a party with so marked an affinity with socialist ideas could not have come about except under its direction and aegis. This is an answer, however, which fits the facts too neatly, a trap of which we must beware, since it conveniently hides much more complicated motivations and tensions.

If we are, then, to accept this as one reason, we must also consider and investigate alternative explanations. These, it is suggested, are to be found in the particular history of Azerbaijan: its internal development, and its relationship with the rest of Iran and especially Tehran and the central government. This province has traditionally occupied a special position and received special attention from the Nevertheless Azerbaijan had clearly defined local characteristics, and to some extent can be said to possess a national character. In contradistinction to the majority of Iranians who are Persian-speaking, the Azerbaijanis use a language closely related to Turkish. Their sense of national pride, which expresses itself in a events such as the Tobacco protest of 1891, their participation in, and leadership of, the Constitutional Revolution of 1905 , and the revolt of Khiyabani occasioned by the 1919 Treaty made by the Prime Minster with the British. It was thus the centre of what the Iranian rulers saw as 'revolutionary' ideas.

The Azerbaijan democratic movement arose out of general dissatisfaction with the central government's policies and the regime in Tehran. It was fueled by the readiness of the Azerbaijanis to fight for reforms after years of suppression, and given the opportunity to develop through the presence of Soviet forces sympathetic to democratic movements in Iran. Following the oil treaty signed with the USSR, the localized policy of the Firqa-yi Democrat was universalized to extend over the whole of Iran. By so doing, they received further support and backing from other progressive parties in the country, and to gather with others, formed the Freedom Front in November, 1946. At the end of one year, the movement had reached such strength as to be able to take over Tehran: it refrained from doing so, however, as a consequence of Qavam's conciliatory attitude. This was in all probability their greatest mistake, for it gave time and occasion to Qavam to plan their destruction.

Qavam suppresses the Firqa-yi Democrat, and the Hizb-I Kumala-yi Khuzestan, and the Tudeh Party, and rejected the Soviet oil concession all on the Western support in the face so aggression from the Soviet Union.

\section{RESEARCH METHODOLOGY}

This research has been conducted thoroughly on the question the failure of the Fiqa - Yi Democrat Azerbaijan, also try to compare different opinions of various historians about FiqaYi Democrat Azerbaijan . It is obvious that discussion of the failure of the Firqa-yi Democrat-I Azerbaijan must be set in the context of foreign intervention within Iran, for the presence of Russia and Britain was a major factor, if not the principle one, in Iranian politics from the beginning of the twentieth century

In this research, I tried to use published books and scholar's articles in different scientific journals, mainly I have used newspapers of the period between 1945-46, also public record office papers. 


\section{Theoretical Basic}

This research has been conducted thoroughly on the question weather failure of the Firqa-yi Democrat Azerbaijan was due to foreign intervention or internal circumstances and central government pressure. And also concentrate on the main materials dealing with the failure of this movement and try to analyze different opinions of different historians.

It is obvious that discussion of the failure of the Firqa-yi Democrat-I Azerbaijan must be set in the context of foreign intervention within Iran, for the presence of Russia and Britain was a major factor, if not the principle one, in Iranian politics from the beginning of the twentieth century Despite this situation, insufficient work has been done to establish either the extent or nature of internal circumstances, in Iran and more particularly, within Azerbaijan, this being so, we shall concentrate in this article upon internal events and influences concerning the Firqa-yi Democrat Azerbaijan, mentioning outside causes only where absolutely necessary, and ask the reader to go to the innumerable books already published for detailed analysis of this part of our subject.

\section{RESEARCH FINDINGS}

It is obvious that discussion of the failure of the Firqa-yi Democrat-I Azerbaijan must be set in the context of foreign intervention within Iran, for the presence of Russia and Britain was a major factor, if not the principle one, in Iranian politics from the beginning of the twentieth century "1".Despite this situation, insufficient work has been done to establish either the extent or nature of internal circumstances, in Iran and more particularly, within Azerbaijan, this being so, we shall concentrate in this article upon internal events and influences concerning the Firqa-yi Democrat Azerbaijan, mentioning outside causes only where absolutely necessary, and ask the reader to go to the innumerable books already published for detailed analysis of this part of our subject "2".

Azerbaijan was, at the end of WWII, spring 1945, a bone of contention that thereby forced upon itself the attention of foreign powers and of Tehran, and suffered accordingly. America, Britain and the Soviet Union wee faced at the end of the war with a major problem in Iran, as a consequence of the presence of both Soviet and British occupation forces in the country. Disagreement over withdrawal of these became sharp, and it was this conflict over that marked the beginning of the Cold war that ensued after 1945 "3".

These difficulties were compounded by the relationships that had evolved between the foreign powers and the various factions in Iran, and their mutual antagonism. The central government was traditionally pro-West, and accorded with the latter's desire to see the Azerbaijan democratic movement crushed "4".Firqa-yi Democrat, however, resisted both the central government and the presence of foreign powers in Iran, but was supported (not as a puppet) by the USSR.

Iranian attitudes towards the presence of outside powers in the country were more complex than simple approval or disapproval. While the central government was pro-West, it still wished for the removal of all foreign troops, particularly so as to be able to crush the Firqa-yi Democrat-I Azerbaijan as part of the attempt to re-establish their power in both Tehran and the provinces " 5 ".

The Majlis, on the other hand, was split over the propriety of a foreign presence, primarily Soviet. The Conservatives within parliament argued for the immediate withdrawal of Soviet troops in order to let Tehran regain its governmental stature. The minority Communists, 
backed by liberals, believed that as long as the Soviets retained their presence in Azerbaijan, the central government might see their way to at least a limited number of much-needed reforms; if the USSR withdrew, it was almost certain that these reforms would remain uninstituted, since the Firqa-yi Democat would then not be given a chance to establish itself "6".

This latter situation did in fact obtain: Soviet troops withdrew on March 2nd, 1946, and the central government, backed by the West, succeeded in suppressing the Firqa-yi Democrat, preventing the democratic movement from spreading through Iran, and throughout the Middle East, the fear of the West "7".

In the spring of 1945, Azerbaijan was not an international problem among the ranks of the Big Powers; it was more seriously an internal issue facing the Iranian government's foreign relations. The discussion of Iran at Yalta in February 1945"8", was delegated by Churchill, with the agreement of Stalin and Roosevelt, to their respective foreign ministers, who were felt to be capable of dealing with the issue "9. It was therefore not considered by the leaders to be a major area of conflict. Nevertheless, events soon escalated within Iran that drew the Powers into hostility.

The first disturbances occurred with a rebellion of tribesmen I Reza'iyya during February/March 1945. Reza'iyya (Orumieh) was in the Soviet zone, and the central government requested permission from the Soviet Union to send troops to crush the rebellion. The Soviets agreed to one battalion from Tabriz, but Tehran insisted that a regiment was necessary, and dispatched one from Saqqiz. This was halted on the border of the Soviet zone, an act which angered Tehran, and worried the West since it was in violation of Article 4 of the Tripartite Treaty of 1942, which stated that: "the Soviet authorities cannot prohibit the entry of Iranian troops into the Soviet zone for internal administrative purposes" "10".

The Soviet military attaché in Tehran announced that the column had been halted because if large numbers of Iranian troops entered the Soviet zones, clashes with Russian personnel would inevitably occur. The Soviet Union considered the army, police and gendarme units already in the Soviet zone sufficient to deal with the rebellion.

This explanation was not fully accepted either in Tehran or in the West, and served, in fact, to intensify the problem. The Soviet action served also to reinforce the belief of many Iranians that their problems derived primarily from foreign presence and intervention in Iran. This belief was expressed so strongly that Mohammad Reza shah sent a note to both Soviet and British governments requesting notification of the date of withdrawal of their troops "11".

The official date set for the removal of all occupying forces from Iran was in fact disputed by the protagonists. Tehran believed that the six months alluded to in the Tripartite Treaty were defined according to the defeat of Germany as being the end of the war. The central government insisted that since neither the Soviet Union nor Iran herself had taken any part in the war against Japan, these six months could not be thus defined according to the Japanese surrender. It therefore demanded withdrawal of foreign troops by November 1945, not March 1946 "12".

The Articles 5 of the Tripartite Treaty itself stated that "all foreign forces should withdraw from Iran no later than six months after the war with Germany and her associates had ended"."13"This clause allowed for an interpretation defining the end of the war as the 
Japanese surrender, and contributed towards the confusion that existed and that was exploited by the Soviet Union.

A formal request was thus made on May 19th, 1945, by Iran's Foreign Minister, Sipahbudi, to the three Big Powers for the immediate withdrawal of their troops from Iran "14".Britain agreed to this request on two conditions: that the Soviets withdraw simultaneously "15", and that British oil interests in Iran would be safeguarded. The newly-appointed American ambassador to Iran, Wallace Murray, informed Tehran that American plans for withdrawal were underway, but that 3,500 American personnel would remain in Iran in order to protect their military installations, and 1,500 of these would be placed in Abadan to look after American oil plants and refineries etc.

Iran was encouraged by this reply from the United States. Prime Minister Sadr further approached Murray, asking for American support to stop British and Russian interference in Iran's internal affairs. Murray assured Sadr that Iran was becoming a major international issue and it was therefore appropriate that the Iranian issue should be discussed at the Potsdam Conference on July 21, 1945 "16".

This promise was duly kept, and Iran was made the subject of debate between the three Big Powers. Eden, the British Foreign Minister "17", proposed an immediate withdrawal from Tehran, and a gradual withdrawal from the provinces"18". Stalin rejected the second half of the proposal, and the final agreement reached called only for the immediate withdrawal of troops from Tehran "19".The Potsdam Conference decided that the Iranian issue should be further discussed at the Foreign Ministers meeting in London in September, 1945.

The United States gave re-assurances to Iran following the end of the Potsdam Conference that she would continue using her influence to ensure the rapid withdrawal of troops from Iran, and that she respected Iran's independence and integrity. The U.S. government also made suggestions to Tehran concerning Iran's internal security: a rapprochement between Conservatives and Liberals in the country should be effected in order to stabilize the Iranian post-war political situation, and a Commission with members form Iran, Britain and the Soviet Union set up to study their differences, and especially Iran's internal situation and circumstances "20". Notice of American withdrawal was finally given to Iran on July 28, 1945, by George Byrnes, secretary of State, through the U.S. ambassador in Tehran. The date proposed was November 1, 1945, but this was a unilateral move by America, for the Soviet Union and Britain both intended removal of their forces only by March 2, 1946 "21".

This 'agreement to disagree', as it were, over the withdrawal of Big Power troops from Iran soon turned into sharper antagonism among the Big Three, as a result of internal events within Iran during August/September, 1945.

The pressure against the democratic movement, particularly from the Tudeh Party, that ensued during this period was country-wide, but it was especially harsh in Azerbaijan. Azerbaijan was both exploited by the central government and neglected by it, a combination policy designed, unintentionally, to strengthen the Azerbaijani resolve. This resulted in the establishment of the Firqa-yi Democrat Azerbaijan on September 3, 1945.

The Firqa-yi Democrat was given support at this time by the Soviet Union. The Soviets believed that an Azerbaijan autonomous movement was a legitimate right under the Constitution, and did not consider it therefore as an uprising or rebellion against the central government in 
Tehran Furthermore, the Soviets declared after the war their aim and role of supporting all democratic movements against fascist elements in national governments "22".In the case of Iran, the USSR was doubly suspicious of the central government, since it was both reactionary and pro-western. Since the Soviets had a border with Iran, which it was anxious to safeguard "23", the Soviet regime played its cards to limit Iranian power by backing the Firqa- yi Democrat."24"

This development caused great concern in the West, as well as the central government, as it was felt by Britain and America that the Firqa-yi Democrat might be turned by the Soviets from a mere interest group into a fully-fledged movement " 25 ". Thereby, the Soviet Union would be enabled to infiltrate the central government, known to be pro-West "26", and assume a position of influence. A similar process was suspected also in the Soviet interest given to the Tudeh Party "27".

Western propaganda thus began, claiming that the USSR intended the annexation of Azerbaijan "28". This claim was justified on the grounds that Firqa-yi Democrat leaders had received training in the Soviet Union. The Firqa must thus be a Soviet puppet, being used as the agent to annex Azerbaijan.

Evening's statements denied that these claims were true, for he regarded a large number of Firqa-yi Democrat meetings himself, and clearly pointed out that in no way was the party seeking annexation to the Soviet Union "29".

The central government went even further in maligning the Firqa-yi Democrat. It announced that Soviet military personnel in mufti were leading the revolt in Azerbaijan. This claim was completely unrealistic, however, since the Azaris could easily be distinguished from Russians, nor were there that number of Soviet troops in Azerbaijan. Furthermore, it was denied by the Iranian Army present in Azerbaijan at the time, which had no sympathies with the Firqa-yi Democrat "30".

The true reason behind the Western propaganda lay in the West's opposition to Soviet expansion in Iran and the Middle East in the face of their own interests and anti-Communist policies. This fear is reflected in Truman's Statement that the Soviet Union desired domination of at least a part of Iran, if not all, and that this was part of her plan to control entirely all the oilfields within the Middle East "31", and also in the recognition that any kind of democratic movement in the Middle East threatened their interests and must therefore be crushed and prevented from spreading " 32 ".

The central government propaganda was motivated by three factors. It was concerned that its pro-Western attitude should continue, simultaneously with Western influence in Iran, and thus demanded the suppression of the left element in Iran. Neither was the central government willing to share its power in the provinces, nor to institute reforms. Lastly, because the central government was not democratic, any democratic movements within Iran presented a challenge to its authority and power. Thus it was inherently opposed to the Firqa-yi Democrat.

American concern over the Iranian situation continued with the sustained active interest shown by the Soviet Union particularly in Azerbaijan. At the 'Foreign Ministers ' Conferences in London, September, September 1945 "33" . America declared that she was withdrawing her forces from Iran starting on November 1st, 1945. It was her wish that due to the delicate situation involving Iran herself and the Big Powers, that Britain and the Soviet Union should 
remove their troops beginning from January 1st, 1946 "34" in order to stabilize the area and the growing conflict. Byrnes proposal was rejected by both Bevin and Molotov, who nevertheless eventually agreed to a withdrawal date of March 2, 1946 "35".

The situation in Azerbaijan rapidly deteriorated in the period following the Foreign Ministers Conference. Government announcements proclaimed that the Soviets had introduced 12,000 additional troops into Bandar Pahlavi(Anzali), an act which seriously worried the West. The anxiety of the central government, however, centered rather on the growth of the Firqa-yi Deimocrat, and increased its resolve to crush the movement. Tehran ordered troops to Azerbaijan, but the Iranian army was halted at Qazvin by Soviet forces. The Soviet commander announced that an attack on Azerbaijan was an implicit attack on the Soviet Union herself, since Azerbaijan was a Soviet-occupied zone. Hakimi was sufficiently cautious to order the Iranian troops to remain in Qazvin until he had received an explanation from the Soviet attaché in Tehran. A formal note was sent to the attaché on November 23, 1945, requesting explanation of incident "36".The reply given stated that the Soviet Union was attempting to maintain order in the area: an increase of forces would escalate the disturbance, at the same time as being unnecessary, since bloodshed would ensue, and the USSR would be forced to bring more Soviet troops into Azerbaijan to keep the balance. Thereby the situation would only be worsened.

The central government remained unconvinced by the Soviet reply, and thus, to circumvent the military problem, made a request to George Byrnes through Husayn Ala, the Iranian ambassador in Washington, for American intervention. Husayn Ala declared to Byrnes that the Firqa-yi Democrat was not an indigenous movement, but engineered and inspired by the Soviet Union "37" .It therefore posed a threat to Iran's independence and integrity, and American influence was sought to counter this development.

The reason behind this approach to the United States was the unwillingness of the central government to negotiate directly with the Azerbaijanis themselves. It was this refusal that was primarily responsible for the magnification of Iran's internal affairs into an international issue. For the first time, therefore, at the beginning of 1946, the internationalization of the Azerbaijan problem was mooted within Iran: Humayunfar, Under Secretary for Foreign Affairs, announced that if the Azerbaijani movement could not be forestalled through negotiations,(i.e. with the Soviets ) Iran was willing to formulate a case to present before the U.N. Security Council "38".Early in 1946, a start was indeed made on just such as formulation by the Shah and his government "39".

This appeal to America bore fruit at the subsequent Foreign Ministers Conference held in Moscow in December 1945. During the discussion concerning Iran, Byrnes intimated quite forcefully to the Soviet Union that if she did not withdraw her support for the Firqa-yi Democrat, America would feel obliged to support the resolution, intended to be submitted to the U.N., proposed by Iran.

Stalin's reply indicated to Byrnes that while America could be sure of Soviet withdrawal at a later date, a Soviet presence in Azerbaijan was currently imperative in order to protect her oil interests, since the central government was itself incapable of preventing sabotage. Her ultimate withdrawal was dependent upon the attitude shown by Tehran to the Soviet Union.

The British also made a suggestion to avoid taking the matter before the U.N. Security Council and thereby threatening any other discussions by antagonizing the USSR. On 16th December, 
in Moscow, Bevin thus proposed a Tripartite Commission composed of Britain, America and the Soviet Union. The Commission would be responsible for examining the Iranian problem and working towards its resolution. The American response was positive, but the Soviet reaction was unfavorable, and the central government, under Hakimi, was also not keen. Tehran feared that the Commission might recommend a Provincial Council in which the Firqayi Democrat might be represented. Hakimi, while he realized the legitimacy of such a Council under the Constitution, yet resisted the participation of the Firqa and desired the crushing of the movement. Iranian liberals further disapproved of the establishment of a Commission of Big Powers, because they considered Azerbaijan to be an internal affair and foreign powers to have no right to intervene therein "40" . Nationalists, too, rejected the proposal - Dr. Musaddiq, for example, stated that a Commission might again divide Iran into two zones of influence as in 1907 "41".Musaddiq made an alternative suggestion that the Iranian government should make representations to the Soviet Union and to the Azerbaijanis to resolve the problem. He urged that the pro-West Hakimi government step down and a neutral government be elected as the only means to effect the necessary steps towards negotiations " 42 ".

Iran as a whole thus rejected this proposal, and favored taking the matter before the U.N., believing that the Soviet injection of troops into Azerbaijan violated the Charter of the United Nations. This indicates clearly that the central government, backed by Iranian conservatives, was responsible for internationalizing the Azerbaijan war, due to their inherent biases: in sharp contrast to the liberal belief, and wish, that the issue was capable of internal resolution, the pro-West, anti-Soviet and anti-Firqa-yi Democrat prevalence within the central government caused the matter to be turned into an international problem.

The Iranian government was pressured into accepting the proposal of a tripartite commission by the British, who indicated that if it was rejected, Hakimi would be left to face the Soviet Union alone "43".Hakimi was able; however, to force a modification of the proposal whereby the Commission should discuss the issue with Iranian representatives in Iran itself, primarily concerning the withdrawal of foreign troops according to the Tripartite Treaty of 1942 and the Tehran Declaration of 1943 "44". Hakimi then made representations to the Soviet Union, which were rejected with a refusal to participate in the Commission: such a Commission, it was declared, was a threat to Iran's sovereignty and integrity "45".

Western attitudes to the modifications demanded by the Hakimi government were also divided: American opinion was quite in favor of them, but the British disagreed, and insisted that Bevin's model should stand, as it was.

Internal opposition to the plan came from with the Majlis. Dr. Musaddiq, for example, thanked the Soviet Union for its refusal to participate, for if she had, the uniting of the Big Powers would have brought an end to Iranian sovereignty. The Powers should rather institute a democratic government in Iran and respect her independence and integrity, which they themselves guaranteed.

As a result of these divisions and conflicts, Hakimi decided to cancel the whole arrangement for a Commission "46" .Tehran was then left with three options: negotiations with the Azerbaijanis themselves, negotiations directly with the Soviet Union, or recourse to the resolution of the problem through the U.N.

The American ambassador, Murray, urged Hakimi to take the first option, approaching the Firqa-yi Democrat with a negotiating team made up of his most able members of Cabinet. 
The second option was strongly was strongly supported by radicals, liberals and nationalists such as Musaddiq - in Iran, and also to a lesser extent by Britain and America. The emphasis here was laid on total efforts to reach direct negotiations with the Soviet Union, but this did not foreclose final resort to the U.N. for resolution of the Problem "47".

The majority opinion backed the internationalization of the problem through recourse to the U.N. Security Council. The Shah Conservative and pro-British deputies within the Majlis necked this intention, with the result that Hakimi, while himself preferring direct negotiations with both Azerbaijan and the Soviet Union, was limited by his own government's attitude "48".

Therefore, at the beginning of 1946, the Hakimi government officially adopted recourse to the United Nations "49". Thus Hasan Taqizada, the head of the Iranian delegation to the U.N., wrote a formal letter to the Secretary of Security Council, saying that the Soviet Union was interfering in the internal affairs of Iran. The Azerbaijan affair thus threatened world peace, and the Iranian therefore had made great attempts at reaching negotiations with the Soviet government, since these had failed, she was now asking for the issue to be put on the Security Council agenda.

On January 24th, 1946, Vyshinsky, the head of the Soviet U.N. delegation, denied the allegations made by Iran against the USSR. He asserted the Soviet view that Azerbaijan was indeed an internal Iranian affair, and that therefore the matter could and should be resolved through direct negotiations with the people of Azerbaijan, and neither with herself or through the U.N. According to the Irano-Soviet Treaty of 1921 and the Tripartite Treaty of 1942, the Soviet Union had a legitimate right to maintain troops in Iran. She could not at present afford to withdraw forces because her interests were threatened by the reactionary Hakimi government. Vyshinsky concluded the speech with a comparison with British troops maintained in Indonesia and Greece: if these remained, the Soviet Union reserved the right to maintain troops in Iran "50".

Taqizada replied on January 26th, claiming before the Security Council that Iran's case was based on the true facts, and should therefore be examined carefully and thoroughly by the U.N.

During this exchange within the U.N., a major change occurred within the Iranian government. Pressure from general reaction against Hakimi's policies, combined with opposition inside the Cabinet, particularly from Dr. Musaddiq, weakened Hakimi's power. Consequently, unable to resolve these difficulties, he found himself forced to resign. On January 20th, he stated: "Now that I have succeeded in putting the Iranian case before the Security Council, I am resigning"."51"

Hakimi's resignation produced great surprise in the West. It was thought that the Iranian affair might now be withdrawn from the agenda of the Security Council. However, Intizam, the Foreign Minister, announced that Hakimi's resignation had been called for in order to make negotiations with the Soviet Union easier. Nevertheless, if these failed, Iran would return the issue to the U.N." $52 "$

The obvious successor to Hakimi was Ahmad Qavam. Qavam was a native Azerbaijan, who ostensibly supported the need for reforms, and who was a more acceptable figure to the Soviet Union, with long political experience. Thus, he was elected Prime Minister and formed the new Cabinet, on January 26th, 1946."53" 
The Azerbaijan movement, while being democratic, modern and progressive, achieving many reforms, thus fell victim to international politics and intrigues and was sacrificed to factors and interests external both to Azerbaijan itself and to Iran."54"

Apart from those external factors enumerated above and the opposition from central government, a further crucial reason or failure was disunity amongst the progressive movement generally and central leadership of the movement in particular. The talk of unity did not translate into practice; Qavam exploited this weakness and thus systematically destroyed،the Fiqa - Yi Democrat movement in Azerbaijan . “55”

\section{CONCLUSION}

The Azerbaijan movement, while being democratic, modern and progressive, achieving many reforms, thus fell victim to international politics and intrigues and was sacrificed to factors and interests external both to Azerbaijan itself and to Iran.

The Firqa-yi Democrat leaders were freedom lovers, reformists, progressivisms; old experienced politicians, with good educations, who wanted democratic rights for Azerbaijan and for the whole of Iran, instead of its exploitation. Azerbaijan had also been known for centuries as the seat of popular uprisings in Iran, manifested in its primary role in the Constitutional Revolution.

The Soviet military and political advisors to Firqa-yi Democrat withdrew from Azerbaijan three days before the invasion, taking with them the heavy arms which the Soviet Union had supplied to movement, and leaving the Local Army solely with light weapons. Furthermore, the Azerbaijan military commanders received orders from the Soviets to retreat from Qafankuh to Tabriz. Pishavari himself was given personal instructions not to resist, and urged together with all those who were under threat of death to flee to the Soviet Union Pishavari was therefore compelled to leave Azerbaijan for the USSR and was succeeded as leader of Firqa-yi Democrat by Biriya. Biriya subsequently declared the surrender of Azerbaijan on 11th December, 1946.

However, as a result of international pressure in December 1946 Pishavari was forced into exile in the Soviet, Union, which was an appropriate although misunderstood place of exile, since "He was the friend of the Soviet Union. not its servant .He later requested from the Soviet government permission to return to Azerbaijan to resume the struggle for autonomy. Immediately after this request, however pishavari was killed in an automobile accident .It is still unclear whether his death was deliberately brought about or accidental future events may possibly shed some light on the circumstances of the death of a man whose whole life was directed towards the defending and upholding of Azerbaijan rights and whose memory will always be held dear by Azerbaijanis.

The primary factor in that led to the collapse of the Azerbaijan movement lay in the withdrawal of support by the Soviet Union. Confusion still exists over the radical alteration in Soviet policy: some observers believe that it was a result of the promise of an oil concession, together with the view that Azerbaijan should be the internal affair of Iran, and opposition to Firqa-yi Democrat from within Azerbaijan itself. These reasons, however, do not do justice to the complexity or truth of the issue. Two alternative explanations can be seriously put forward: the threat made by the United States to drop an atomic bomb on the Soviet Union if she did not withdraw her support from Azerbaijan, or from similar movements in the rest of the world, a threat which the Soviet Union at that time could not return. More likely, is the suggestion that 
the Soviet Union, America and Britain came to an agreement whereby Soviet influence was approved in China in return for withdrawal of support from the Firqa regime, Gen. Markos Vafiades in Greece, the Communist Party of Italy, and other communist parties throughout the world."

\section{Refrences}

1. Ramazani, Iran's Foreign Policy, 1941-73, Charlottesville, University Press of Virginia, 1975; Partin, M.W., US-Iranian Relations 1945-7, North Texas State University, 1977; Tabari, K., Iran's Policies towards the United States During the Anglo-Russian Occupation 1941-1946, Columbia University, 1967; Kuniholm, The Origins of the Cold War in the Middle East, Princeton, 1980.

2. Partin, , M, W ,1977, United State-Iranian Relations 1945-47, p.55.

3. Tulsiram, (n.d.), The History of the Communist Movement in Iran, Bhopal p.105.

4. Khandagh, N , 2010 , The Democratic Movement in Iran ,s Azerbaijan province in 20th

5. Century : a Critical Analysis“, Geopolitics Quarterly, vol.5, No.3, p.p. 106-133[in Persian].

6. Eveling to Sec. of State Bevin, October 13th, 1945.

7. Kumaramangalam, M. 1946, Iran at the Crossroads, Bombay, p.58

8. Farquhar to Bevin, April 18, 1946, p.3, [E3499/5/34]. PRO.

9. The main concern in the discussion was the Iranian bill refusing further oil concessions during the war supported by Eden, but opposed by Molotov. For more details, see: Foreign Relations 1945, VIII, p.365 (Washington, D.C. 1969(.

10. Kuniholm, B,1980, "The origins of the cold War in the Near East "p.308.

11. Partin,. M, W ,1977, United State-Iranian Relations 1945-47, p.57.

12. Feiss, 1945 Between War and Peace: Postdam Conference, Princeton, 1960, p.302; Foreign Relations, VIII, p.371.

13. Kuniholm, B,1980, "The origins of the cold War in the Near East " ,p.143.

14. Farquhar to Bevin, April 18th, 1976, op. cit., p.3.

15. Khandagh , N , 2005 , "Qavam and International Conflict “ , Humanities , Vol , 12 , N . 1 . p.p .43-53

16. Foreign Relations 1945, VIII, p.372.

17. Kuniholm, B,1980, "The origins of the cold War in the Near East ", p.260.

18. Eden, 1960, The Reckoning, Boston, , p.633.

19. Khandagh, N , 2010 , The Democratic Movement in Iran ,s Azerbaijan province in 20th

20. Century : a Critical Analysis“, Geopolitics Quarterly, vol.5, No.3, p.p. 106-133[in Persian].

21. Foreign Relations 1945, VIII, pp. 396-399.

22. Henry Roberts and Wilson, 1953, Britain and the U.S.: Problems and Co-operation, New York, , p.191; Farquhar to Bevin, op.cit., p.4.

23. Eveling, S. October 13, 1945, American Consul in Tabriz, to George Byrnes,.

24. Doenecke, j. 1972, “Iran's Role in Cold War Revisionism”, Iranian Studies, Spring Summer, , p.99.

25. Doenecke, j. 1972, “Iran's Role in Cold War Revisionism”, Iranian Studies, Spring Summer, „, pp.1-3.

26. Doenecke,. , j. 1972, “Iran's Role in Cold War Revisionism”, Iranian Studies, Spring Summer, , p.99.

27. Ramazani, "The Republic of Azerbaijan and the Kurdish People's Republic", Studies on the Soviet Union II (1971), p.458.

28. Seton-Watson, H. 1969, Neither War nor Peace: The Struggle for Power in the Postwar World, New York, Praegar, , p.70.

29. Partin, M, W ,1977 , United State-Iranian Relations 1945-47 , p.75. 
30. Personal interviews with Clos. Sharifi and Javadiyan, March/April, 1982.

31. H.S. Truman, Memoirs, New York, New America Library 19, p.574.

32. Kumaramanglam, M. 1946,. Iran at the Crossroads, Bombay, p.47.

33. Tabari, T, 1976, "Jami-a yi Iran Dar Dawra-yi Reza shah(,Iranian society in Reza Shah Reign) Tehran ., p.189.

34. Farquhar to Bevin April 18th, 1976, op. cit.., p.4.

35. Farquhar to Bevin April 18th, 1976, op. cit.., p.4.

36. Farquhar to Bevin April 18th, 1976, op. cit.., p.4.

37. Kuniholm, B,1980, "The origins of the cold War in the Near East “., p.281.

38. Kuniholm, B,1980, "The origins of the cold War in the Near East "., p.281.

39. Doenecke, j. 1972, “Iran's Role in Cold War Revisionism”, Iranian Studies, Spring Summer,., p.100.

40. Ustuvan, ,K, 1951, “Siyasat-I Muvazana-yi Manfi Dar Mijlis-I Chardahum.,( Negative balance policy in 14th Parliament ) Vol. II, p.223.

41. Ustuvan, ,K, 1951, "Siyasat-I Muvazana-yi Manfi Dar Mijlis-I Chardahum. ( Negative balance policy in 14th Parliament ), Vol. II, p.218.

42. Razm,. T, 1976, “Jami-a yi Iran Dar Dawra-yi Reza shah, (,Iranian society in Reza Shah Reign) Tehran 267, p.988.

43. Fatimi, N.S. 1954, Oil Diplomacy Powderkeg in Iran, New York, , p.283.

44. Tabari, , T, 1976, “Jami-a yi Iran Dar Dawra-yi Reza shah, (,Iranian society in Reza Shah Reign) Tehran p.230.

45. Ustuvan, Siyasat-I Muvazana-yi Manfi dar Majlis-I Chahardahum, .,( Negative balance policy in 14th Parliament ) Tehran, Vol. II, p.233.

46. Tabari, T, 1976, "Jami-a yi Iran Dar Dawra-yi Reza shah(Iranian society in Reza Shah Reign), Tehran., p.988.

47. Khandagh, N, 2014, "Geopolitical Analysis of Azerbaijan Autonomous Movement",

48. Geopolitics Quarterly, Vol.9 , NO .4 , p.p. 180-202[in Persian].

49. Tabari,. , T, 1976, "Jami-a yi Iran Dar Dawra-yi Reza shah, (.Iranian, society in Reza Shah Reign ) Tehran, p.238.

50. Rahbar, no. 678, 1st Farvardin, 1325 (21st March, 1946(.

51. For the Soviet point of view, see Doenecke, j. 1972, "Iran's Role in Cold War Revisionism”, Iranian Studies, Spring Summer,..., pp.100-101.

52. New York Times, January 22, 1946.

53. Partesan, J.G., 1973, Soviet-American Confrontation: Post War Reconstruction and the Origins of the Cold War, Baltimore, , p.179.

54. Iran-I Ma, no.494, 11th Farvardin, 1325 (31st March, 1945(.

55. Ibrahamian,E, Princeton, Wilber, D.N. 1962, 1963., Contemporary Iran, New York, Between Two Revolutions, Praegar, , p.122.

56. Rahbar no.845 , 6th Farvardin, 1325 (26st March, 1945(..

57. Khandagh , N ,2014, Geopolitical Analysis of Azerbaijan Autonomous Movement , , vol.9, No.4, p.p. 180202[in Persian].

58. Harry , S , "Paper of. G. V .Allen, Truman Library , Independence , Mo , USA , p. 65 